\title{
HABITATS WITH LARGE BITTER CRESS (CARDAMINE AMARA L.) IN THE SPRING AREA OF NERA RIVER (SEMENIC MOUNTAINS, ROMANIA)
}

Erika SCHNEIDER-BINDER *

* Karlsruhe Institute for Technology - University of Land Baden-Württemberg and Research Center of the Helmholtz Society, Institute for Geography and Geoecology, Department WWF-Institute for Floodplain Ecology, Josefstrasse 1, Rastatt, Germany, D-76437, erika.schneider@kit.partner.edu, erika.schb@t-online.de

DOI: 10.1515/trser-2017-0002

KEYWORDS: springs, seepage area, clear water habitats, hydrophilous plant communities, oligothermic condition.

\section{ABSTRACT}

The paper presents the spring habitats and their communities edified by the Large Bitter Cress (Cardamine amara L.) in the area of Nergăniţa, a headwater stream of the Nera River included in the "Nature Reserve Semenic Mountains and springs of Nera River". The communities of Large Bitter Cress are situated in and on the springs and spring streamlets situated in the beech forest area, being well adapted to the special site conditions with low water temperatures, low light conditions and humus rich soils. The species composition of the Large Bitter Cress communities and their habitats are presented in strong relation with the habitat conditions and the interrelation with other communities. Finally, the conservation status of the streamlets habitats is analyzed in the context of their importance for the European Natura 2000 network.

ZUSAMMENFASSUNG: Habitate des Bitteren Schaumkrauts (Cardamine amara L.) an Quellbächen der Nera, Semenic-Gebirge, Rumänien.

In vorliegender Arbeit werden die Habitate der Quellen und Quellbächlein sowie die von Bitterem Schaumkraut (Cardamine amara L.) aufgebauten Gesellschaften im Einzugsgebiet des Nergăniţa Baches, ein Hauptquellzufluss der Nera im "Naturschutzgebiet Semenic Gebirge und Nera Quellen” vorgestellt. Die Bestände des Bitteren Schaumkrauts liegen an und in den Quellen und Quellbächlein inmitten von Buchenwald und sind an die Standortbedingungen: niedrige Wassertemperaturen und Lichtverhältnisse sowie humusreichen Boden gut angepasst. Die Artenzusammensetzung der Gesellschaft von Bitterem Schaumkraut und ihr Lebensraum werden in enger Verbindung mit den Habitatbedingungen sowie den Beziehungen zu anderen Gesellschaften vorgestellt. Schließlich wird der Schutzstatus der Quellflur Habitate im Kontext ihrer Bedeutung für das Natura 2000 Netzwerk analysiert.

REZUMAT: Habitatele de stupitul cucului (Cardamine amara L.) în aria pârâiaşelorizvor ale Nerei, Munţii Semenic, România.

Nergăniţei este afluent principal al râului Nera din „Rezervaţia Naturală Munţii Semenic şi izvoarele Nerei”. Grupările de stupitul cucului sunt situate în şi în jurul izvoarelor şi a pârâiaşelor-izvor din pădurea de fag, fiind bine adaptate la condiţiile staţionare caracteristice: temperatură scăzută a apei, lumină redusă, precum şi soluri bogate în humus. Componenţa specifică fitocenozelor edificate de stupitul cucului şi habitat sunt prezentate în strânsă legătură cu condiţiile de habitat şi în relaţie cu comunităţile învecinate. Statutul de conservare este discutat în contextul importanţei habitatului pentru reţeaua Natura 2000. 


\section{INTRODUCTION}

The forest area of the Semenic Mountains in the "Nature Reserve Semenic Mountains and springs of Nera River", part of the National Park Semenic Mountains-Gorge of Caraş (Parcul Naţional Semenic-Cheile Caraşului), Caraş-Severin County in the South-Western part of Carpathians, is sheltering many spring-streamlets frequently in small channels or as larger seepage areas on the slopes of the valleys. These streamlet areas are characterized by water tresses surrounding stones, loose gravel patches with humus soils and on the surface with layers of under composed leaf litter from the antecedent year. They are characterized by plant species adapted to cold and clear waters, like large bittercress (Cardamine amara L.), mentioned as occurring "in wet forests, ditches, around springs, in swampy sites, on the border of streams, quite frequent from the plaines to the sub-alpine level” (Nyárády, 1955). On the list of localities with occurrences of the species in Romania for the Semenic Mountains the species is given "in bogs" without any precise locality (Nyárády, 1955). The altitudinal distribution of the species reaches from the plainer to the hilly, pre-mountain to the higher mountain and subalpine levels (around 1,700-1,900 m), being more frequent on the higher levels of the mountains (Oberdorfer, 2001).

According to additional data concerning ecological requirements as the above mentioned, the species is given (as characteristic for spring areas), alder swamp forests, streamlets and ditches, on wet clay soils with cool, nutrient rich and alkaline seepage water. Also, it is mentioned for more or less regularly flooded soils, but being able as well to survive temporarily without surface running water only on wet, muddy, alkaline and humus soils (Ellenberg et al., 2001; Oberdorfer, 2001).

From the phytocoenological point of view the bittercress (Cardamine amara) is mentioned as characteristic species of the class Montio-Cardaminetea $\mathrm{Br}$.- $\mathrm{Bl}$ et Tüxen 1943, Ordre Montio-Cardaminetalia Pawlowski 1928, including the alliances Cardaminion amarae Mass 1959 and Cardamino-Montion Br.-Bl. 1926 (Oberdorfer, 2001; Sanda et al., 2008), but it occurs also in phytocoenoses of the alliance Alno-Ulmion Br.-Bl. et Tüxen 1943 em. Th. Müller et Görs 1958, including the sub-alliance Alnenion glutinoso-incanae Lüdi 1921 (Oberdorfer, 1992). The classifications for the order and the subunits, alliances, and sub-alliances are different according to the opinion of different authors (Coldea, 1978).

The alliance, Cardaminion amarae, includes the association CardaminoChrysosplenietum alternifolii Maas 1959 with the characteristic species Cardamine amara, Carex remota, Chrysosplenium alternifolium, Conocephalum conicum, Impatiens noli-tangere, Oxalis acetosella and Plagiochila asplenioides (Boşcaiu, 1971). With an increase of altitude, the floristic composition is changing, the phytocoenoses being more and more interlocked with elements of the tall herbaceous vegetation of Adenostyletalia order of the subalpine level. The phytocoenoses mentioned from Cerna Mountains at the Lunca Berhinei shelter beside the above mentioned species and two other species with subalpine-alpine distribution such are Tozzia alpina and Barbarea lepuznica (Boşcaiu, 1971).

The alliance Cardamino-Montion Br.-Bl. 1926 includes the spring streamlets phytocoenoses of sites with siliceous underground and deficiency in lime, being characterized by species such are Chrysosplenium alternifolium, Chrysosplenium alpinum, Cardamine amara incl. ssp. opizii, Saxifraga heucherifolia, Stellaria uliginosa and Philonotis seriata. 
The habitats of springs and spring streamlets in the Romanian Carpathians are included in the habitat group of fens, bogs, springs, and streamlets, category 54 (Doniţă et al., 2005), with the types R 5418 South-Eastern Carpathian spring communities with Philonotis seriata and Caltha laeta, R 5420 Communities S-E Carpathians fontinale vegetation with Cardamine opizii, 5421 South-eastern Carpathian communities of springs and streamlets with Chrysosplenium alternifolium and Cardamine amara, 5422 Communities of South-Eastern Carpathian habitats of springs and streams with Glyceria nemoralis.

From these habitat types, the type R 5418 "South-Eastern Carpathian spring communities with Philonotis seriata and Caltha laeta" is included according to Gafta and Mountford (2008), in the Natura 2000 habitat type 3220 Alpine rivers and the herbaceous vegetation along their banks. As well the habitat $\mathrm{R}$ 5420, the South-Eastern Carpathian fontinale communities with Cardamine opizii and the habitat R 5423 South-Eastern Carpathian Communities of springs and streamlets with Carex remota and Caltha laeta (Doniţă et al., 2005), are included in the Natura 2000 Habitat type 3220 (Gafta and Mountford, 2008). But the R5421 habitat "South-Eastern Carpathian spring and streamlet communities with Chrysosoplenium alternifolium and Cardamine amara" is lacking in the habitat type 3220 of the Natura 2000 network: although there is locally a very strong interlocking with the other communities included in the mentioned habitat type and cannot be separated from their stands.

Considering these facts, the objective of the present paper is to close a gap with a presentation of montane phytocoenoses edified by Cardamine amara from the beech forest of "Nature Reserve Semenic Mountains and springs of Nera River", which differs from other studied Large Bitter Cress communities through its particular site conditions, and complete in the same time as the list of associations included in the corresponding habitat type of the Natura 2000 network in Romania.

\section{MATERIAL AND METHODS}

During the vegetation period of 2015, researches concerning the riparian habitats were realised in the Caraş and Nera river basins National Park Semenic Mountains-Gorge of Caraş (Parcul Naţional Semenic-Cheile Caraşului), and National Park gorge of Nera and Beuşniţa (Parcul Naţional Cheile Nerei-Beuşniţa). Special attention was given to the riparian vegetation from upstream to downstream, i.e. the riparian forest galleries (subject of another paper) the natural tall herbaceous vegetation, the pioneer communities on the banks and the river bed and as well the particular situation of the spring area of rivers. Samples were taken according to the method of Braun-Blanquet with the seven degree abundance-dominance scale, (BraunBlanquet, 1964; Borza and Boşcaiu, 1965). Also considered were the aspects concerning the structure of the habitats in strong relation to the stream stretch and the water dynamics.

The samples taken are included in a phyto-coenological table and grouped according to characteristic species of the different phytocoenological units, their abbreviation being mentioned below in table 1. For the ecological analysis, indicator values for wetness (W), nitrogen (N), Light condition (L), are also considered (Ellenberg et al., 2001). The phytocoenoses are discussed in comparison with other mentioned communities edified by common watercress, (Oberdorfer, 1977; Sanda et al., 2008). The habitats are as well analysed and presented in the context of the European Union habitats, (EUR28, 2013; Gafta and Mountford, 2008; Doniță et al., 2005). The nomenclature of species is used according to Sârbu et al. (2013), and Ciocârlan (2009). 


\section{RESULTS AND DISCUSSION}

The spring area of Nergăniţa, a headwater stream of the Nera River presents a structured valley with many small spring-streamlets, forming frequently tresses around gravel escutcheons on an altitude of 1,100-1,300 m a.s.l. (Fig. 1). In the small valleys of the Nergăniţa sub-basin, the water is frequently seeping under the layer of different sized gravels mixed with the beech forest leaves and those decomposed from the preceded years, forming together a loose humus layer of various thicknesses. These all together constitute a wet channel complex with open, and by leaves covered cold, seeping or running clear waters, offering special conditions for plants adapted to such conditions, (Fig. 1). The most abundant species in this microhabitat inside the beech forest habitat is the large bittercress, (Cardamine amara R. Br.). The species occurs in the area under half-shadow to half-light conditions accompanied by other half-shadow species, (indicator values three-five according to Ellenberg et al., 2001), characteristic for beech (Fagetalia), forests or Grey Alder forest galleries (Alnion incanae), such are: Chrysosplenium alternifolium, Scrophularia umbrosa, and Impatiens noli-tangere. As well, characteristic species for tall herbaceous communities of clearings or forest borders which occur are Lunaria rediviva and Doronicum austriacum. According to Boşcaiu (1971a), Impatiens noli-tangere can be considered as a differential species for the lower montane levels of the association.

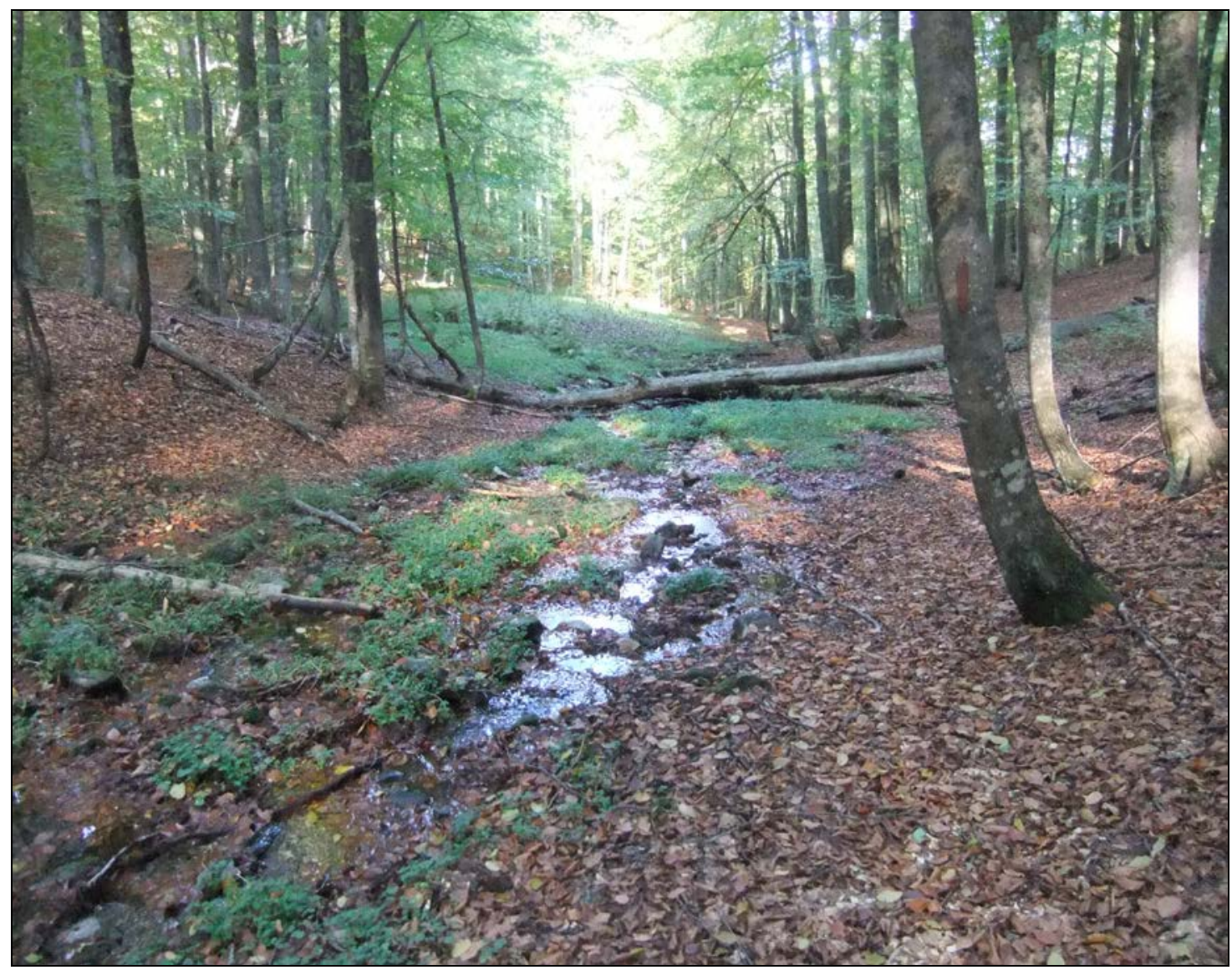

Figure 1: Spring streamlet in the sub-basin of Nergăniţa with typical vegetation of large bittercress (Cardamine amara), 2015. 
In general, the structure of the phytocoenoses is given by the alternation of stones/gravels, water tresses and the large bittercress individuals, with the accompanying species being poorly represented, (Tab. 1, column 1-6). They are characteristic for the phytocoenological units of Fagetalia, Adenostyletalia, Molinietalia and mainly the alliances Filipendulion and Alnion incanae. The low number of species is given by the shadow conditions of the forest and the cold seeping water of the area, being a limiting ecological factor for species which are not adapted to such conditions.

The Cardamine amara phytocoenoses are included in the association Cardaminetum amarae (Rübel, 1912), Br.-Bl. 1926 s. str. which is synonymous with ChrysosplenioCardaminetum (Tx. 1937), Mass. 1959 (Drăgulescu, 1986, 1995; Boşcaiu 1971a, 1971b). The samples taken in the Nera River spring area have different characteristics from those described from other areas of the Carpathians, (Boşcaiu, 1971a, 1971b; Coldea, 1978; Drăgulescu, 1986, 1995). The differences are given by their existence in the forested area with special conditions of light, and the species living almost in half-light conditions with a small number of other accompanying species adapted to half-light conditions (Ellenberg et al., 2001). The floristic composition of the studied phytocoenoses is relatively stabilized by an ecological homeostasis, which is in strong dependence with the low, but continuous discharge, and the low and more or less constant temperature of the water and running water, with oligothermic regime, mostly along the vegetation period being only around $5^{\circ} \mathrm{C}$, (Boşcaiu, 1971a).

On the forest border and in contact with the streamlet community, with Cardamine amara, are some larger escutcheon like seepage area with high abundance-dominance of Filipendula ulmaria, Caltha palustris, Geum rivale (Figs. 2 and 3). In that area the interlocking of stands of Cardamine amara with those of Caltha palustris, Geum rivale and Carex remota can be observed. On such a relatively small area, a clear delineation of the different associations is difficult; but it can be stated that the streamlets with running water are settled by Cardamine amara and the seeping water area more by Caltha palustris, Geum rivale and Carex remota. A strong relation between large bittercress stands and transition stages between communities of the Montio-Cardaminetalia to those of the Molinietalia, including the alliances Filipendulion, (Filipendulo-Petasition), and Calthion is clearly visible.

Table 1: Community of Large Bittercress Cardaminetum amarae (1-6) and Carici remotae-Calthetum palustris Coldea (1972) 1978 (= Syn. Carici remotae-Cardaminetum amarae Dihoru 1964).

\begin{tabular}{|l|l|c|c|c|c|c|c|c|c|c|c|}
\hline & Number of sample & 1 & 2 & 3 & 4 & 5 & 6 & & 7 & 8 & 9 \\
\hline & Covering degree \% & 60 & 70 & 75 & 60 & 55 & 50 & & 70 & 90 & 85 \\
\hline & & & & & & & & $\mathrm{K}$ & & & \\
\hline Mo-Card & Cardamine amara & $\mathbf{3}$ & $\mathbf{4}$ & $\mathbf{3}$ & $\mathbf{3}$ & $\mathbf{3}$ & $\mathbf{1}$ & $\mathrm{V}$ &. &. &. \\
\hline C-Mo, Al inc & Chrysosplenium alter. & 2 & 1 & 2 & 1 & 2 & 3 & $\mathrm{~V}$ &. &. &. \\
\hline Al inc. T. m. & Glecoma hederacea & 1 &. & 1 &. & 1 & 1 & $\mathrm{~V}$ & & & \\
\hline Al inc. & Scrophularia umbrosa & + &. &. &. &. & + & $\mathrm{II}$ &. &. &. \\
\hline Ad. & Doronicum austriacum & + &. & + & 1 &. &. & $\mathrm{III}$ &. &. &. \\
\hline Fagion & Lunaria rediviva & 1 & + & + &. & + & + & $\mathrm{IV}$ &. &. &. \\
\hline Fi, Al inc, Fa & Impatiens noli-tangere &. &. & + & + &. & + & $\mathrm{III}$ &. &. &. \\
\hline Se flu, Al-Pa & Myosoton aquaticum &. &. & 1 &. &. &. & $\mathrm{I}$ &. &. &. \\
\hline $\mathrm{Mo}$ & Geum rivale &. &. &. & 1 &. &. & $\mathrm{I}$ & + & 2 &. \\
\hline $\mathrm{Ca}$ & Caltha palustris &. &. &. & 1 &. &. & $\mathrm{I}$ & + & $\mathbf{2}$ & $\mathbf{3}$ \\
\hline
\end{tabular}


Table 1 (continued): Community of Large Bittercress Cardaminetum amarae (1-6) and Carici remotae-Calthetum palustris Coldea (1972) 1978 (= Syn. Carici remotae-Cardaminetum amarae Dihoru 1964).

\begin{tabular}{|c|c|c|c|c|c|c|c|c|c|c|c|}
\hline & Number of sample & 1 & 2 & 3 & 4 & 5 & 6 & & 7 & 8 & 9 \\
\hline & Covering degree $\%$ & 60 & 70 & 75 & 60 & 55 & 50 & & 70 & 90 & 85 \\
\hline & & & & & & & & $\mathrm{K}$ & & & \\
\hline Fa-alia & Fagus sylv. (regen) & . & . & . & . & + & . & $\mathrm{I}$ & . & . & . \\
\hline $\mathrm{X}$ & Deschampsia caespit. & . & . & . & . & + & . & I & 4 & 1 & 2 \\
\hline $\mathrm{X}$ & Athyrium filix-femina & . & . & . & . & + & . & $\mathrm{I}$ & + & + & . \\
\hline Ae-ion & Chaerophyllum arom. & . & . & . & . & . & + & $\mathrm{I}$ & + & + & . \\
\hline Ru-ion alp & Veratrum album & . & . & . & . & . & . & - & 1 & 1 & . \\
\hline Mo & Angelica sylvestris & . & . & . & . & . & . & - & + & + & + \\
\hline Ad & Rumex alpestris (arif.) & $\cdot$ & . & . & . & . & . & - & + & . & + \\
\hline Fi-ion & Filipendula ulmaria & . & . & . & . & . & . & - & + & 3 & 1 \\
\hline C-Mo, & Carex remota & . & . & . & . & . & . & . & $\cdot$ & 1 & 2 \\
\hline $\mathrm{Ca}, \mathrm{Al}$ inc & Cirsium rivulare & & & & & & & - & + & + & . \\
\hline Art, Ru-ion alp & Urtica dioica &. & . & . & . & . & . & - & + & + & . \\
\hline Mag, Ae-ion & Ranunculus repens & . & . & . & . & . & . & - & . & + & . \\
\hline Arr, Ae-ion, Art & Rumex obtusifolius & . &. & . & . &. & . & - & . & + & . \\
\hline & Sphagnum sp. & . & . & . & . & . & . & - & . & . & 1 \\
\hline
\end{tabular}

Localisation of samples: between 1,137-1,319 m a.s.l.; altitude 1,319 m a.s.l., $\mathrm{N} 45^{\circ} 08^{\prime} 828^{\prime \prime}, \mathrm{E}$

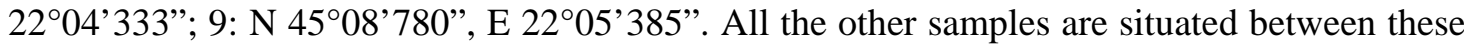
given altitudes and geographical coordinates.

Abbreviations for the phytocoenological units included in the above table:

Ad $=$ Adenostyletalia, Ae-ion $=$ Aegopodion, $\mathrm{Al}$ inc $=$ Alnion incanae, Al-Pa $=$ Alno-Padion, Arr $=$ Arrhenateretalia, Art $=$ Artemisietea, $\mathrm{C}-\mathrm{Mo}=$ Cardamino-Montion, $\mathrm{Ca}=$ Calthion, $\mathrm{Fa}=$ Fagetalia, $\mathrm{Fi}=$ Filipendulion (Filipendulo-Petasition), Mag = Magnocaricion, Mo $=$ Molinietalia, Mo-Card $=$ Montio-Cardaminetea, $\mathrm{Ru}$-ion $=$ Rumicion alpinae, Se-flu = Senecion fluviatilis, T.m. $=$ Trifolion medii, $\mathrm{x}=$ in different groups of classes.

Only in the seepage area on the border of the forest, an interlocking with other species of small, cold water courses, spring and seepage areas can be observed. Apart from the interlocking with phytocoenoses characteristics for wet tall herbaceous vegetation of the alliances Filipendulion (Filipendulo-Petasition), Calthion (order Molinietalia), and the order Adenostyletalia, initial stadia of bogs with Sphagnum species and of wet meadows edified by Deschampsia caespitosa can be observed.

The studied seepage area (Figs. 2 and 3) outside the forest is mainly composed by a tall herbaceous fringe on the upper part of the slope edified mainly by Filipendula ulmaria (1), followed by Caltha palustris (2), Geum rivale with Carex remota (3), Geum rivale with Caltha palustris (4), all together being bordered on both sides by a small streamlet dominated by Cardamine amara. It can be stated that these vegetation patches take part in three different phytocoenological units, i.e. Filipenduletum ulmariae W. Koch 1926, Carici remotaeCalthetum palustris Coldea (1972), 1978 and Cardaminetum amarae (Rübel 1912), Br.-Bl. 1926. The first of these associations is included in the habitat type: 6430 Hydrophilous tall herb fringe communities of plains and of the montane to alpine levels and the other two associations in the habitat type 3220, Alpine rivers and the herbaceous vegetation along banks. 
Seeing the common bittercress (Cardamine amara) in strong relation with the habitat conditions, of the other phytocoenoses units included in the habitat type 3220, and as well the strong interlocking between the above discussed spring and streamlet phytocoenoses, the inclusion of the higher montane large bittercress phytoconoses with their stenotop characteristics in this habitat type of community interest is justified.

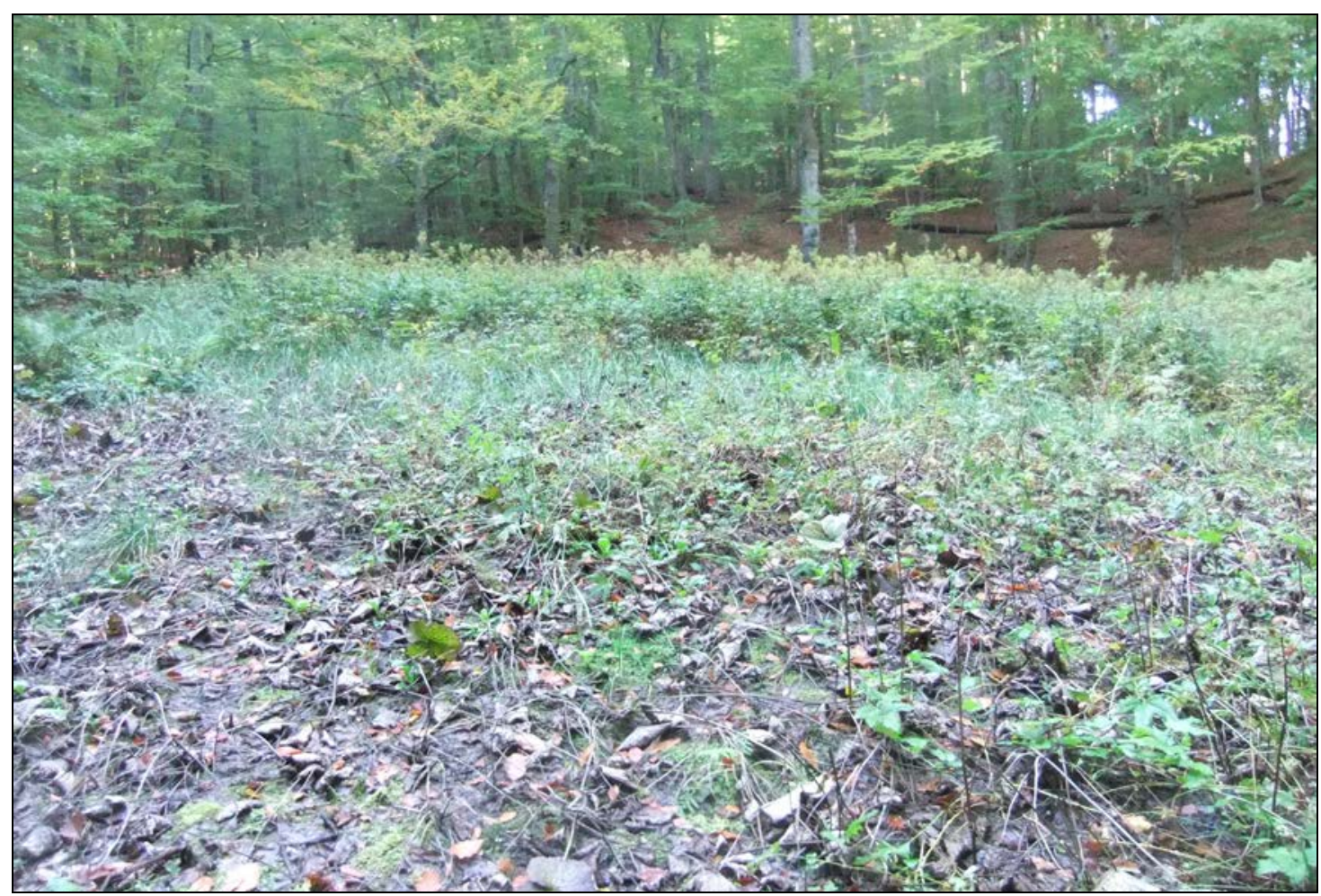

Figure 2: Large seeping streamlet area on the border of a beech forest in the Nergăniţa Spring area (autumnal aspect).

The occurrence of the large bittercress in the Semenic Mountains area in the large network of springs and spring streamlets is an indicator for the high quality of the beech forest area of the "Nature Reserve Semenic Mountains and springs of Nera River", as it is a typical habitat type for areas with clean waters in the frame of the beech forest area with a same high quality and biodiversity. 


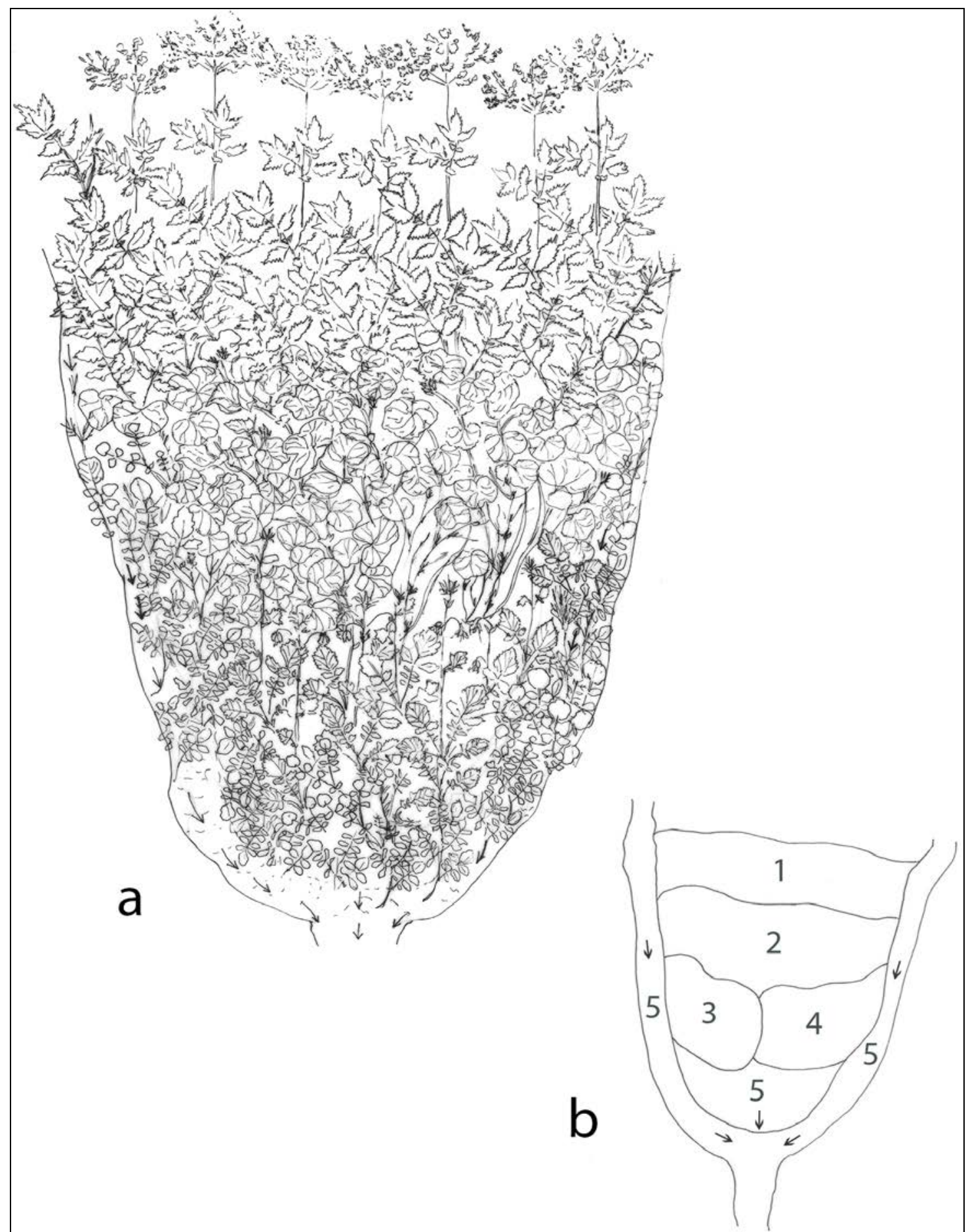

Figure 3: Escutcheon like seepage area between small streamlets with repartition of dominant species a: seeping water area with the structure of the vegetation cover, $\mathbf{b}$ : repartition of the dominant species: 1 Filipendula ulmaria, 2 Caltha palustris, 3 Geum rivale and Carex remota, 4 Geum rivale and Caltha palustris, 5 Cardamine amara on the border and in the streamlets. 


\section{CONCLUSIONS}

The vegetation of the spring area of the large bittercress (Cardamine amara L.) in the sub-basin of Nergăniţa, a headwater stream of the Nera River, is an example for spring and spring streamlet habitats with a stenotopic character and a stable structure. The habitat type and the communities and their species composition are in strong relation with the ecological limiting factors such are the more or less constant water temperatures during the vegetation period, and the shadow condition under the canopy of the beech forest crowns. Cardamine amara, the dominant species, is well adapted to these cold and clear running waters of the spring streamlets. The large bittercress stands at the altitude of 1,100-1,350 m of the Semenic Mountains and have an intermediary position between those of higher montane levels and those of the lower montane levels as well as the lower hill areas and plains and have their particularity due to the mentioned site conditions.

The seepage area on the border of the forest are remarkable for their complexity with the interlocking of different phytocoenoses, but all being well adapted to the spring streamlets conditions and also have a stable character. The shore from hygrophilous tall herbaceous fringe habitats to phytocoenoses edified mostly by Caltha palustris with Geum rivale and Carex remota and at least to some small patches of bogs, demonstrates the dynamic character of the area with stable ecological conditions, i.e. the natural hydrological regime of the streamlets and the good state of the forest. For their conservation and sustainability the appropriate conservation management of the forest with its streamlets, with all micro and macro-habitats is of high priority.

\section{ACKNOWLEDGEMENTS}

Many thanks to Ovidiu Adascăliţei from WWF Romania, branch office Reşiţa for his valuable help and assistance during field activities in the National Parks Semenic-Cheile Caraşului/Semenic Mountains - Caraş gorge and Cheile Nerei-Beuşniţa/Gorge of NeraBeuşniţa. 


\section{REFERENCES}

1. Borza A. and Boşcaiu N., 1965 - Introducere în studiul covorului vegetal, Edit. Academiei R.S. România, Bucureşti, 340. (in Romanian)

2. Braun-Blanquet J., 1964 - Pflanzensoziologie. 3. Auflage, Springer Verlag Wien, 865. (in German)

3. Boşcaiu N., 1971a - Vegtaţia fontinală din Munţii Ţarcu, Godeanu şi Cernei, Muzeul Brukenthal Studii şi Comunicări Ştiinţe Naturale Sibiu, 16, 123-133. (in Romanian)

4. Boşcaiu N., 1971b - Flora şi vegetaţia Munţilor Ţarcu, Godeanu şi Cernei. Edit. Academiei R. S. România, Bucureşti, 494. (in Romanian)

5. Ciocârlan V., 2009 - Flora ilustrată a României. Pteridophyta et Spermatophyta. Edit. Ceres, Bucureşti, 1141. (in Romanian)

6. Coldea G., 1978 - Vegetaţia fontinală şi palustră din Munţii Plopiş, Studii şi Cercetări de Biologie, Seria Biologie vegetală, Bucureşti, 30, 2, 125-134. (in Romanian)

7. Doniţă N., Popescu A., Paucă-Comănescu M., Mihăilescu S. and Biriş I. A., 2005 - Habitatele din România, Edit. Tehnică Silvică, Bucureşti, 496. (in Romanian)

8. Drăgulescu C., 1986 - The spring-growing vegetation in the basin of Sadu-Valley (CindrelŞtefleşti Mountains), Contribuţii Botanice, Cluj-Napoca, 189-193.

9. Drăgulescu C., 1995 - Flora şi vegetaţia din bazinul văii Sadului. Edit. Constant, Sibiu, 355. (in Romanian)

10. Ellenberg H., Weber H. E., Düll R., Wirth V. and Werner W., 2001 - Zeigerwerte von Pflanzen in Mitteleuropa/Indicator values of plants in Central Europe, Scripta Geobotanica, 18, 1-264, Erich Goletze KG, Göttingen. (in German)

11. EUR28, 2013 - Interpretation Manual of the European Union habitats. European Commission DG Environment, 144.

12. Gafta D. and Mountford O. (eds), 2008 - Manual de interpretare a habitatelor Natura 2000 din România. Risoprint, Cluj-Napoca, 101. (in Romanian)

13. Nyárády E. I., 1955 - Fam. Cruciferae B. Juss., Genul Cardamine 255-275, in Flora R. P. R., III. Edit. Academiei Republicii Populare Române, Bucureşti. (in Romanian)

14. Oberdorfer E., 2001 - Pflanzensoziologische Exkursionsflora für Deutschland und angrenzende Gebiete, Achte, stark überarbeitete und ergänzte Auflage, Verlag Eugen Ulmer Stuttgart, 1051. (in German)

15. Oberdorfer E., 1977 - Süddeutsche Pflanzengesellschaften, I, Fels- und Mauergesellschaften, alpine Fluren, Wasser, Verlandungs- und Moorgesellschaften. Pflanzensoziologie Band 10, VEB Gustav Fischer Verlag Jena, 311. (in German).

16. Sanda V., Öllerer K. and Burescu P., 2008 - Fitocenozele din România. Sintaxonomie, structură, dinamică şi evoluţie, Edit. Ars Docendi, Universitatea din Bucureşti, 570. (in Romanian)

17. Sârbu I., Ştefan N. and Oprea A., 2013 - Plante vasculare din România. Determinator ilustrat de teren, Edit. Victor B. Victor, Bucureşti, 1231. (in Romanian) 